\title{
KEMISKINAN DAN PERKEMBANGAN WILAYAH DI KABUPATEN BOYOLALI
}

\author{
Wahyuni Apri Astuti dan Muhammad Musiyam \\ Staf Pengajar Fakultas Geografi Universitas Muhammadiyah Surakarta \\ Jl. A. Yani Pabelan Kartasura Tromol Pos I Surakarta 57102 \\ Telp. (0271) 717417 Psw. 151-153, Fax. (0271) 715448 \\ E-mail: wapriatutiapri@yahoo.com \\ E-mail: muhammadmusiyam@yahoo.com
}

\begin{abstract}
This research is based on the facts: first that, Boyolali is one of the regions which implement intensively many kinds of program in solving the poverty which gets the finance from APBD, central government and international institutions, eventhough the proportion of the poor society increases significantly. The proportion of poor society increases 20,8\% in 2002 becomes 38,26\% in 2006. Second, seen from the regional development indicator, it is shown that between one region and the others has various levels of the varieties of development. The objectives of this research are: first, the understanding of the distribution and of the poverty level in this region. Second, the understanding of the relationship between distribution of poverty level and the regional development level. Third, the understanding of the factors which influence the regional development. The method used in this research is secondary data analysis. The analysis unit of this research is village. The data resources are taken from the report of the identification result of poor families and the primary data is taken from BAPPEDA Boyolali. The primary data is a number of poor families, the regional scope and the use of farmland, the long street to account the regional accessibilities and the number and the distribution of social and economical facility in each village. The result is presented on the map with the analysis unit of the village. The represented map are the distribution level of poverty per village. To determine the relationship between the level of poverty and regional development uses the technique of qualitative and quantitative analysis. The qualitative analysis technique used is the analysis of the map of poverty distribution, analysis map of regional development and harmonious relationship between the level of regional development and poverty. The quantitative analysis technique used is the analysis of correlation statistic product moment. The results of this research are: first, there is distribution variation of poverty level, there is relationship between distribution of poverty level and natural resources endowment.The region with lower resources endowment (up land region) bave higher poverty level than the region with higher natural resources endowment (law land region) and conversel. Second, there is negative relationship between regional development level and poverty level.Third, the factors which influence the level of regional development are the economical and social facility of the region and accessibilities.
\end{abstract}

Keywords: poverty level, regional development

\section{PENDAHULUAN}

Strategi penanggulangan kemiskinan di Indonesia telah mengalami beberapa kali pergeseran. Tahap awal pembangunan jangka panjang (PJP) I. Penanggulangan kemiskinan ditempuh dengan strategi tidak langsung (indirect attack) melalui kebijakan 
ekonomi makro untuk mencapai pertumbuhan ekonomi yang setinggitingginya. Fokus kebijakan ini diarahkan untuk meningkatkan sektor-sektor dan kelompok pelaku ekonomi yang mempunyai profitabilitas yang tinggi. Industri besar diletakkan sebagai sektor unggulan (leading sector), dan kelompok swasta besar dijadikan sebagai agen utama penggerak perekonomian Nasional.

Strategi penaggulangan kemiskinan tersebut didasarkan pada argumentasi bahwa dengan pertumbuhan ekonomi yang tinggi, kemiskinan akan dapat berkurang melalui mekanisme efek tetesan ke bawah (trikcle-down effects), namun program ini belum mencapai hasil yang diharapkan. Jumlah penduduk miskin secara absolut belum berkurang secara berarti. Peningkatan kesejahteraan ternyata lebih banyak dinikmati oleh segelintir orang. Tanpa disadari, kesenjangan ekonomi, sosial, dan spasial menjadi semakin lebar. Dengan kata lain, melalui penerapan strategi ini, di satu sisi telah membangun terbentuknya konsentrasi kapital, namun di sisi lain, secara bersamaan telah melahirkan marginalisasi kota atas desa dan penduduk kaya atas penduduk miskin.

Menyadari kegagalan strategi tersebut, dalam menanggulangi kemiskinan, strategi pembangunan berikutnya mulai bergeser ke pertumbuhan dengan pemerataan (growth with distribution) dan pemenuhan kebutuhan pokok (basic needs). Berbagai program penanggulangan kemiskinan diterapkan, antara lain: (1) pentransferan sumber-sumber pembangunan dari pusat, seperti program Inpres yang bertujuan untuk mengembangkan ekonomi daerah; (2) peningkatan akses masyarakat miskin kepada pelayanan sosial, seperti: pendidikan, kesehatan, keluarga berencana, air bersih, dan sebagainya; (3) perluasan jangkauan lembaga perkreditan untuk rakyat kecil (Kupedes. BKK, Kredit Bimas, dan sebagainya; (4) pembangunan infrastuktur ekonomi pedesaan, khususnya infrastruktur pertanian; dan (5) pengembangan kelembagaan yang terkait dengan penanggulangan kemiskinan, seperti Program Pengembangan Wilayah (PPW). Program Kawasan Terpadu (PKT), Program Peningkatan Pendapatan Petani Kecil (P4KT), dan sebagainya (Moeljarto, 1993). Harus diakui, kinerja dari kombinasi program-program tersebut secara inkremental dan gradual telah menunjukkan hasil yang menggembirakan. Antara tahun 1976-1996 jumlah penduduk miskin mengalami penurunan dari 45 juta jiwa menjadi sekitar 15,6 juta jiwa (Musiyam, 1998).

Beberapa program penanggulangan kemiskinan tersebut terkait erat dengan konsep pengembangan wilayah yang berorientasi pada perbaikan hidup kelompok miskin, terutama yang ada di wilayah pedesaan. Argumentasi yang mendasari program-program tersebut adalah sebagai berikut. Pertama, peningkatan kesejahteraan hidup kelompok miskin tidak bisa dipisahkan dengan sumberdaya yang mereka miliki. Oleh karena itu, program penanggulangan kemiskinan perlu berbasis pada optimalisasi sumberdaya lokal. Atau dengan kata lain, program penanggulangan kemiskinan perlu mempertimbangkan kondisi dan potensi lokal dimana kelompok miskin berada. Kedua, permasalahan dasar kemiskinan adalah ketidakmampuan mereka menjangkau pelayanan-pelayanan dasar, baik pelayanan sosial maupun pelayanan ekonomi. Oleh karena itu, fasilitas-fasilitas pelayanan tersebut secara spasial harus didekatkan pada mereka.

Kabupaten Boyolali merupakan salah satu wilayah yang secara intensif mendapatkan program penanggulangan kemiskinan, baik dari Pemerintah Daerah, 
Pemerintah Pusat, maupun lembagalembaga internasional. Namun demikian, proporsi penduduk miskin di kabupaten ini mengalami peningkatan yang signifikan. Berdasarkan data yang dihimpun oleh Kelompok Kerja Penanggulangan Kemiskinan Kabupaten Boyolali, proporsi penduduk miskin di daerah ini mengalami peningkatan dari 20,8\% tahun 2002 menjadi 38,26\% pada tahun 2006 (Laporan Pembangunan Manusia Indonesia 2004, BPS, BAPENAS, UNDP dalam Pemantauan dan Evaluasi Pelaksanaan Program Kompensasi Pengurangan Subsidi Bahan Bakar Minyak tahun 2005 dan Kelompok Kerja Penanggulangan Kemiskinan Kabupaten Boyolali, BPS, 2006)

Berdasarkan data penduduk miskin tersebut, maka diperlukan pembangunan infrastruktur pelayanan fasilitas pelayanan sosial, ekonomi, masyarakat untuk penanggulangan kemiskinan dan peningkatan perkembangan wilayah. Aspek-aspek perkembangan wilayah dalam penelitian ini meliputi perbedaan tingkat keterjangkauan wilayah (acessibility) yang ditunjukkan dengan kerapatan jalan, yaitu: rasio panjang jalan dengan luas wilayah, dan persebaran infrastruktur pelayanan sosial dan ekonomi, seperti fasilitas pendidikan, kesehatan, pasar, jasa keuangan dan perdagangan.

Tingkat perkembangan wilayah di Kabupaten Boyolali bervariasi antara bagian wilayah satu dengan bagian wilayah lainnya. Secara umum, tingkat perkembangan wilayah dataran rendah dengan sistem pertanian sawah dan mempunyai tingkat keterjangkauan tinggi, relatif lebih cepat dibanding dengan wilayah dataran tinggi dengan sistem pertanian lahan tegalan. Basis perekonomian di wilayah dataran tinggi adalah pertanian lahan kering dan peternakan, sedangkan basis perekonomian di wilayah dataran rendah adalah pertanian padi sawah. Penelitian ini bertujuan untuk: pertama, mengetahui distribusi dan tingkat kemiskinan, kedua, kaitan antara distribusi tingkat kemiskinan dengan perkembangan wilayah, dan ketiga, mencari faktor-faktor yang mempengaruhi perkembangan wilayah.

Penelitian ini penting dilakukan karena studi tentang kemiskinan umumnya lebih banyak menguak dimensidimensi non keruangan, sehingga program penanggulangan kemiskinan yang direkomendasikan kurang terkait dengan program pengembangan wilayah.

\section{METODE PENELITIAN}

Penelitian ini dilakukan di Kabupaten Boyolali, propinsi Jawa Tengah. Kabupaten ini mempunyai luas wilayah 101.510,20 ha, terdiri atas 19 kecamatan yang terbagi atas 267 kelurahan/desa (BPS, Kabupaten Boyolali, 2005). Penelitian ini menggunakan metode analisa data sekunder dan unit analisis dalam penelitian ini adalah desa.

\section{Pemilihan Daerah Penelitian}

Pemilihan Kabupaten Boyolali sebagai daerah penelitian dengan alasan: Kabupaten Boyolali merupakan salah satu daerah yang intensif menerima program bantuan penanggulangan kemiskinan, namun proporsi penduduk miskin di Kabupaten ini mengalami peningkatan dari 20,8 persen tahun 2002 menjadi 38,26 persen pada tahun 2006. Disamping itu dilihat dari indikator perkembangan wilayah, terdapat variasi tingkat perkembangannya.

\section{Pengumpulan dan Pengukuran Data}

Penelitian ini dilakukan melalui beberapa tahap. Tahap pertama, pengumpul- 
an data, adapun data yang dikumpulkan meliputi: jumlah rumah tangga miskin per desa, tingkat aksesibilitas wilayah, jumlah dan persebaran fasilitas pendidikan, fasilitas kesehatan, fasilitas ekonomi: pasar, pelayanan jasa keuangan dan perdagangan. Sumber data diambil dari laporan hasil identifikasi penduduk miskin dan data pokok yang dikeluarkan oleh BAPPEDA Kabupaten Boyolali.

Tahap kedua, data yang terkumpul kemudian diolah yaitu menghitung proporsi rumah tangga miskin, mengukur tingkat fasilitas sosial dan ekonomi serta aksesibilitas wilayah (Tabel 1). Adapun pengolahan data dilakukan dengan teknik skoring. Teknik skoring digunakan untuk menentukan klasifikasi tingkat kemiskinan berdasarkan rasio antara jumlah rumah tangga miskin dengan total jumlah rumah tangga penduduk per desa. Berdasarkan persentase rumah tangga miskin tertinggi dan terendah maka tingkat kemiskinan dikelompokkan menjadi tiga, yaitu: kemiskinan rendah yaitu persentase rumah tangga miskin $<25 \%$, tingkat kemiskinan sedang yaitu $25-50 \%$ dan tingkat kemiskinan tinggi jika diatas 50\%. Langkah selanjutnya disajikan dalam peta tingkat kemiskinan.

Selanjutnya menentukan tingkat perkembangan wilayah yaitu merupakan akumulasi dari nilai skor fasilitas sosial, ekonomi dan eksesibilitas. Berdasarkan jumlah skor tertinggi dan terendah maka tingkat perkembangan wilayah dibuat menjadi 3 hirarki.

\section{Analisis Data}

Tahap ketiga yaitu analisis data dengan menggunakan teknik kualitatif dan kuantitatif. Analisis kualitatif dilakukan dengan cara interpretasi peta distribusi tingkat kemiskinan dengan perkembangan wilayah. Analisis ini dengan menggunakan teknik Sistem Informasi Geografi (SIG). Dalam penelitian ini dilakukan analisis keselarasan, untuk mengetahui hubungan asosiatif antara perkembangan wilayah dengan kemiskinan.

Analisis keselarasan dilakukan untuk mengetahui hubungan lebih lanjut, apakah kemiskinan mempunyai hubungan dengan perkembangan wilayah. Diasumsikan bahwa untuk desa-desa yang mempunyai bubungan selaras, jika perkembangan wilayah rendah dengan tingkat kemiskinan tinggi; perkembangan wilayah tergolong sedang dengan tingkat kemiskinan sedang dan perkembangan wilayah yang tinggi dengan tingkat kemiskinan rendah. Hubungan yang tidak selaras terjadi, jika tingkat perkembangan wilayah tinggi tetapi tingkat kemiskinannya tingi dan perkembangan wilayah rendah dengan tingkat kemiskinan yang rendah. Hubungan cukup selaras terjadi, jika tingkat perkembangan wilayah sedang mempunyai kemiskianan rendah; perkembangan wilayah rendah mempunyai kemiskianan sedang; perkembangan wilayah yang tinggi mempunyai kemiskinan sedang serta perkembangan wilayah yang sedang dengan kemiskinan yang tinggi.

Analisa statistik yang digunakan adalah analisa korelasi product moment untuk mengetahui faktor-faktor yang mempengaruhi perkembangan wilayah.

\section{HASIL DAN PEMBAHASAN}

\section{a. Distribusi Rumah Tangga Miskin.}

Kabupaten Boyolali merupakan salah satu kabupaten yang memiliki masalah kemiskinan. Menurut data dari Komite 
Tabel 1. Variabel dan Klasifikasi Skor Masing-masing Variabel

\begin{tabular}{|c|c|c|c|}
\hline No. & Variabel & Klasifikasi & Skor \\
\hline \multirow[t]{5}{*}{1} & Fasilitas Pendidikan & TK & 1 \\
\hline & & $\mathrm{SD}$ & 2 \\
\hline & & SLTP & 3 \\
\hline & & SLTA & 4 \\
\hline & & PT & 5 \\
\hline \multirow[t]{5}{*}{2} & Fasilitas Kesehatan & Tempat Praktek Dokter & 1 \\
\hline & & Puskesmas Pembantu & 2 \\
\hline & & Puskesmas Perawatan & 3 \\
\hline & & Poliklinik Swasta & 4 \\
\hline & & BKIA & 5 \\
\hline \multirow[t]{4}{*}{3} & Fasilitas Keuangan & Koperasi & 1 \\
\hline & & BKK & 2 \\
\hline & & $\mathrm{BPR}$ & 3 \\
\hline & & BRI & 4 \\
\hline \multirow[t]{4}{*}{4} & Fasilitas Perdagangan & Restoran/Rumah Makan/ Kedai & 1 \\
\hline & & Toko/Warung/Kios & 2 \\
\hline & & Pertokoan & 3 \\
\hline & & Pasar & 4 \\
\hline \multirow[t]{3}{*}{5} & Aksesibilitas/Keterjangkauan & Jalan Desa & 1 \\
\hline & & Jalan Kabupaten & 2 \\
\hline & & Jalan Propinsi & 3 \\
\hline
\end{tabular}

Sumber: Hasil Analisis Data Primer

Tabel 2. Tingkat Kemiskinan di Kabupaten Boyolali

\begin{tabular}{ccc}
\hline \hline Tingkat Kemiskinan & Jumlah Desa & Persen \\
\hline Rendah & 20 & 7,5 \\
Sedang & 201 & 75,7 \\
Tinggi & 45 & 16,9 \\
\hline Jumlah & $\mathbf{2 6 7}$ & $\mathbf{1 0 0 , 0}$ \\
\hline
\end{tabular}

Sumber: Hasil Analisis Data Sekunder Kecamatan Dalam Angka 2005 


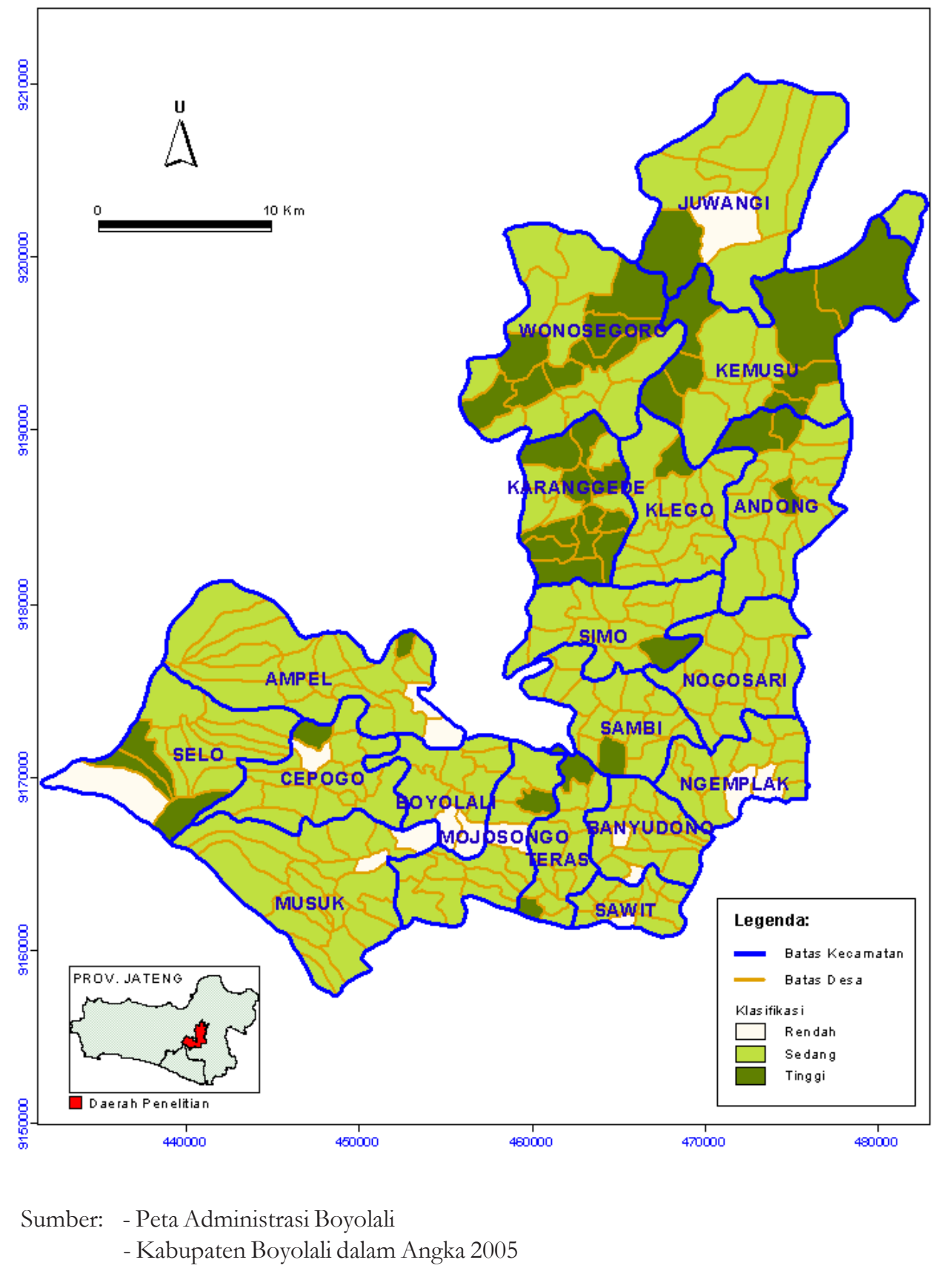

Gambar 1. Peta Sebaran Penduduk Miskin di Kabupaten Boyolali 
Penanggulangan Kemiskinan, jumlah rumah tangga di Kabupaten Boyolali ini sebanyak 248.549 rumah tangga, 38,26\% (95.083 rumah tangga) diantaranya tergolong miskin (menerima bantuan langsung tunai dari pemerintah).

Berdasarkan proporsi rumah tangga miskin terhadap jumlah rumah tangga keseluruhan, maka distribusi tingkat kemiskinan di Kabupaten Boyolali dapat disajikan pada Tabel 2.

Tabel 2 menunjukkan bahwa sebagian besar tingkat kemiskinan desadesa di Kabupaten Boyolali tergolong tingkat kemiskinan sedang dan tinggi, hanya sebagian kecil desa dengan tingkat kemiskinan rendah.

Secara geografis desa-desa yang mempunyai tingkat kemiskinan tinggi sebagian besar terdapat di Kabupaten Boyolali bagian utara, yaitu Kecamatan Juwangi, Wonosegoro, Kemusu, Sambi, Nogosari, Karanggede, Andong dan Kecamatan Klego. Sedangkan desa yang mempunyai tingkat kemiskinan rendah sebagian besar terdapat di wilayah bagian tengah yaitu Kecamatan Boyolali, sebagian desa di Kecamatan Mojosongo, Teras dan Banyudono (Gambar 1).

Temuan ini mengindikasikan adanya hubungan asosiatif antara tingkat kemiskinan dengan kondisi geografi. Desadesa yang mempunyai tingkat kemiskinan tinggi umumnya berada di wilayah-wilayah dataran tinggi dengan sistem pertanian lahan kering dan mempunyai tingkat keterjangkauan yang relatif rendah. Sebaliknya desa-desa yang mempunyai tingkat kemiskinan rendah umumnya terletak di wilayah-wilayah dataran rendah dengan sistem pertanian sawah dan umumnya mempunyai tingkat keterjangkauan yang relatif tinggi. Temuan ini memperkuat teori yang mengatakan wilayah yang mempunyai resources endowment yang relatif rendah (wilayah pertanian lahan kering) bahwa kemiskinan dipengaruhi oleh natural resources endowment, ternyata tingkat kemiskinannya lebih tinggi dibanding wilayah yang mempunyai resources endowment lebih tinggi (wilayah pertanian sawah).

\section{b. Distribusi Fasilitas Sosial dan Ekonomi}

Tingkat fasilitas sosial ekonomi menunjukkan bahwa sebagian besar desadesa di Kabupaten Boyolali mempunyai tingkat fasilitas sosial ekonomi cukup baik, tetapi terdapat $24,3 \%$ desa dengan tingkat fasilitas sosial ekonomi yang jelek.

Analisa sebaran fasilitas sosial ekonomi di Kabupaten Boyolali menunjukkan bahwa, Kecamatan Boyolali, Teras, Banyudono, sebagian Kecamatan Mojosongo dan Ngemplak mempunyai fasilitas sosial ekonomi lebih baik dibanding kecamatan lainnya.

Secara keruangan sebaran ketersediaan fasilitas sosial ekonomi di Kabupaten Boyolali mempunyai 3 pola (Gambar 2). Ketersediaan fasilitas sosial ekonomi tertinggi berada di wilayah tengah, daerah perbatasan di bagian utara dan barat serta pola terpencar pada pusat kota-kota kecil (kecamatan).

Pola ketersediaan fasilitas sosial ekonomi di wilayah bagian tengah berasosiasi dengan jarak dari pusat kota dan aksesibilitas daerah. Wilayah bagian tengah merupakan daerah pusat kota dengan ketersediaan fasilitas sosial ekonomi dan aksesibilitas yang paling tinggi. Semakin jauh dari pusat kota ketersediaan fasilitas sosial ekonomi semakin berkurang.

Wilayah perbatasan di bagian utara dan bagian barat, pada umumnya mempunyai 
Tabel 3. Fasilitas Sosial Ekonomi di Kabupaten Boyolali

\begin{tabular}{ccc}
\hline \hline Tingkat Fasilitas Sosek & Jumlah Desa & Persen \\
\hline Rendah & 65 & 24,3 \\
Sedang & 135 & 50,6 \\
Tinggi & 67 & 25,1 \\
\hline Jumlah & $\mathbf{2 6 7}$ & $\mathbf{1 0 0 , 0}$ \\
\hline
\end{tabular}

Sumber: Hasil Analisis Data Sekunder Kecamatan Dalam Angka 2005

ketersediaan fasilitas sosial ekonomi, aksesibilitas, kemampuan lahan pertanian yang rendah. Sedangkan daerah perbatasan di bagian utara yang meliputi Kecamatan Klego, Wonosegoro, Kemusu, Juwangi dan Simo. Wilayah perbatasan bagian barat yang meliputi Kecamatan Cepogo, Selo, Musuk dan sebagian Ampel umumnya mempunyai ketersediaan fasilitas sosial ekonomi rendah.

Pusat-pusat kota kecil (kota kecamatan) mempunyai ketersediaan fasilitas sosial ekonomi yang baik dengan pola terpencar. Wilayah ini meliputi kota-kota kecil di ibu kota Kecamatan Simo, Nogosari, Andong, Juwangi, Cepogo, Ampel.

\section{c. Aksesibilitas Wilayah}

Tingkat aksesibilitas wilayah diukur berdasarkan kerapatan jalan yaitu rasio antara panjang jalan dengan luas wilayah. Semakin tinggi kerapatan jalan di suatu wilayah, maka aksesibilitasnya semakin tinggi.Hasil penelitian menunjukkan bahwa sebagian besar desa-desa di Kabupaten Boyolali mempunyai tingkat aksesibilitas rendah.

Tingkat aksebilitas wilayah desa/ kalurahan yang berada di bagian tengah, yang merupakan lokasi kota Boyolali, umumnya lebih tinggi dibanding dengan wilayah lainnya (Gambar 3). Secara umum, semakin jauh jaraknya dari pusat kota maka tingkat aksesibilitas wilayahnya semakin rendah. Dengan demikian dapat dikatakan bahwa pola tingkat aksesibilitas wilayah di Kabupaten Boyolali mengikuti pola umum wilayah-wilayah yang perkembangannya belum berada pada tingkat lanjut, yaitu pola distance decay principle.

Selain itu, desa-desa yang dibelah oleh jalan yang menghubungkan antar kecamatan dan jalan kabupaten juga memiliki tingkat aksesibilitas wilayah yang cukup tinggi. Dengan demikian tingkat aksesibilitas wilayah di Kabupaten Boyolali juga mengikuti pola memanjang (ribbon development). Pola ini tersebar di kota-kota kecil di kecamatan Nogosari, Andong, Kemusu, juga terdapat beberapa desa di kecamatan Wonosegoro dan Juwangi.

Wilayah yang berada di perbatasan di bagian barat dan utara umumnya mempunyai tingkat aksesibilitas yang rendah. Wilayah bagian barat merupakan wilayah kaki gunung Merapi dan Merbabu, sedangkan bagian utara merupakan wilayah pegunungan lipatan dengan topografi berbukit dan bergelombang. Wilayah ini umumnya mempunyai kemampuan sumber daya pertanian yang relatif rendah. Dengan demikian temuan penelitian menunjukkan bahwa terdapat asosiasi antara aksesibilitas dengan topografi. 


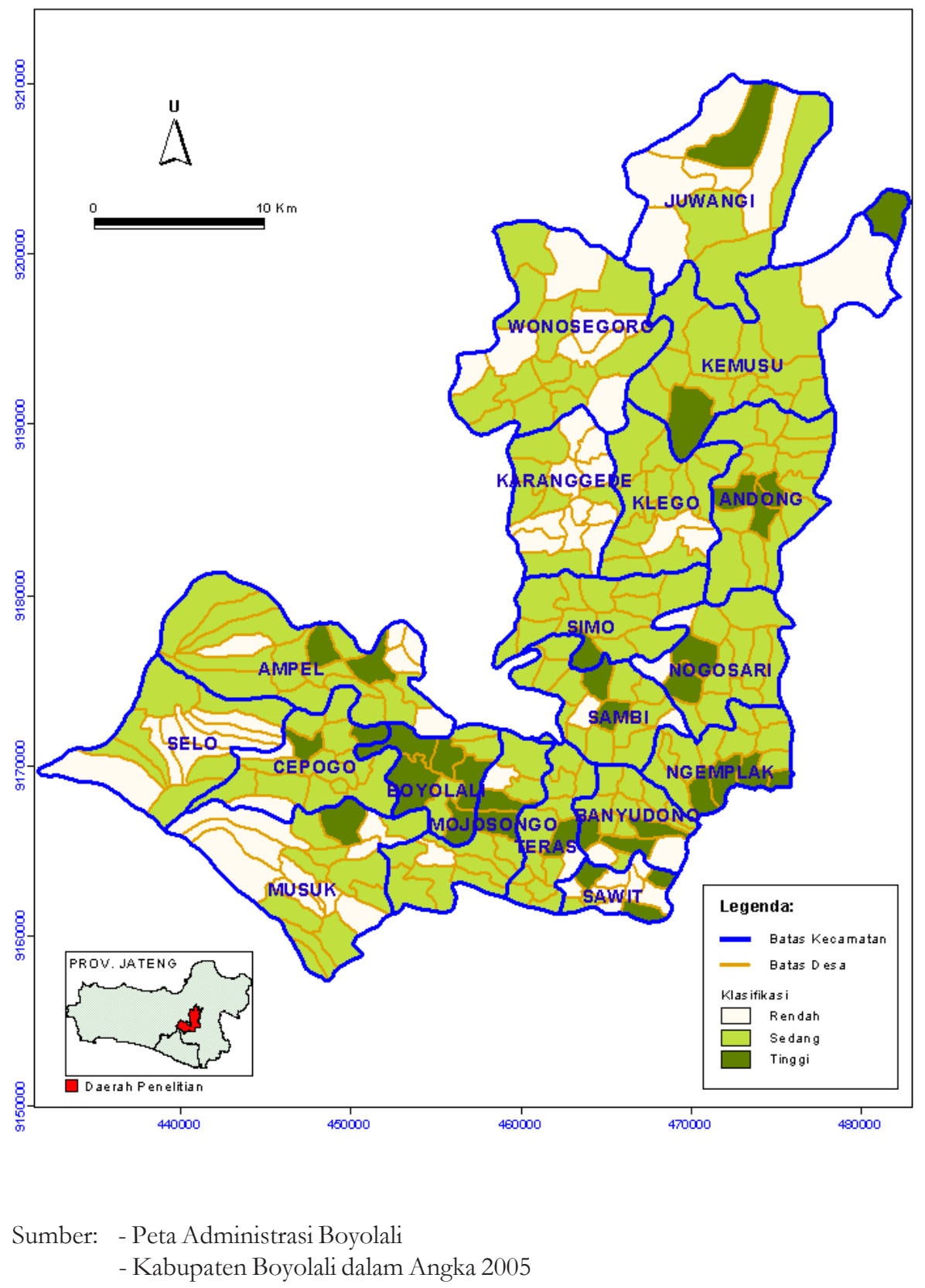

Gambar 2. Peta Sebaran Klasifikasi Fasilitas Sosial Ekonomi Masingmasing Desa di Kabupaten Boyolali 
Tabel 4. Tingkat Aksesibilitas di Kabupaten Boyolali

\begin{tabular}{ccc}
\hline \hline Tingkat Fasilitas Sosek & Jumlah Desa & Persen \\
\hline Rendah & 140 & 52,4 \\
Sedang & 96 & 36,0 \\
Tinggi & 31 & 11,6 \\
\hline Jumlah & $\mathbf{2 6 7}$ & $\mathbf{1 0 0 , 0}$ \\
\hline
\end{tabular}

Sumber: Hasil Analisis Data Sekunder Kecamatan Dalam Angka 2005

\section{d. Kemiskinan dan Perkembangan Wilayah}

Fasilitas sosial ekonomi dan aksesibilitas wilayah mempengaruhi perkembangan wilayah. Dengan tingginya ketersediaan fasilitas sosial ekonomi dan tingginya aksesibilitas wilayah, maka wilayah menjadi berkembang.

Hasil penelitian menunjukkan bahwa sebagian besar desa yang mempunyai tingkat perkembangan tinggi dan tingkat kemiskinan rendah berada di wilayah Boyolali bagian tengah (Gambar 4). Wilayah tersebut tersebar di Kecamatan Boyolali, Ngemplak, Teras, Mojosongo, serta sebagian Kecamatan Nogosari dan Sambi. Sementara itu, desadesa yang mempunyai tingkat perkembangan rendah dan tingkat kemiskinan tinggi tersebar di Kecamatan Kemusu, Juwangi, Wonosegoro, serta sebagian Kecamatan Karanggede dan Andong (wilayah Kabupaten Boyolali bagian utara).

Secara umum, hasil penelitian menunjukkan bahwa desa-desa yang mempunyai tingkat perkembangan wilayah yang tinggi mempunyai tingkat kemiskinan yang rendah. Berdasarkan temuan ini maka dapat dikatakan bahwa perkembangan wilayah mempunyai hubungan yang negatif dengan tingkat kemiskinan. Korelasi antara tingkat perkembangan wilayah dengan kemiskinan ditunjukkan dengan nilai korelasi negatif sebesar - 0,330 pada taraf signifikasi 99\%. yang berarti bahwa hubungan kedua variabel tersebut mempunyai hubungan bersifat erat negatif, perkembangan wilayah naik diikuti turunnya tingkat kemiskinan.

Hasil analisa korelasi product moment menunjukkan bahwa faktor yang mempengaruhi perkembangan wilayah adalah ketersediaan fasilitas sosial, fasilitas ekonomi dan aksesibilitas. Terdapat hubungan yang erat antara perkembangan wilayah dengan ketersediaan fasilitas sosial, fasilitas ekonomi dan aksesibilitas. Hubungan yang erat pada taraf signifikasi 99\% secara berturut-turut menunjukkan angka $0,700,0,815$, dan 0,428 ; yang berarti bahwa hubungan antara variabel - variabel tersebut bersifat erat positif. Naiknya jumlah fasilitas sosial, ekonomi, dan aksesibilitas akan diikuti naiknya perkembangan wilayah. Desa-desa yang mempunyai ketersediaan fasilitas sosial, ekonomi dan aksesibilitas yang tinggi, mempunyai perkembangan wilayah yang tinggi, dan sebaliknya.

Hubungan keselarasan antara perkembangan wilayah dan kemiskinan desa-desa di Kabupaten Boyolali dapat dilihat pada Tabel 5. 


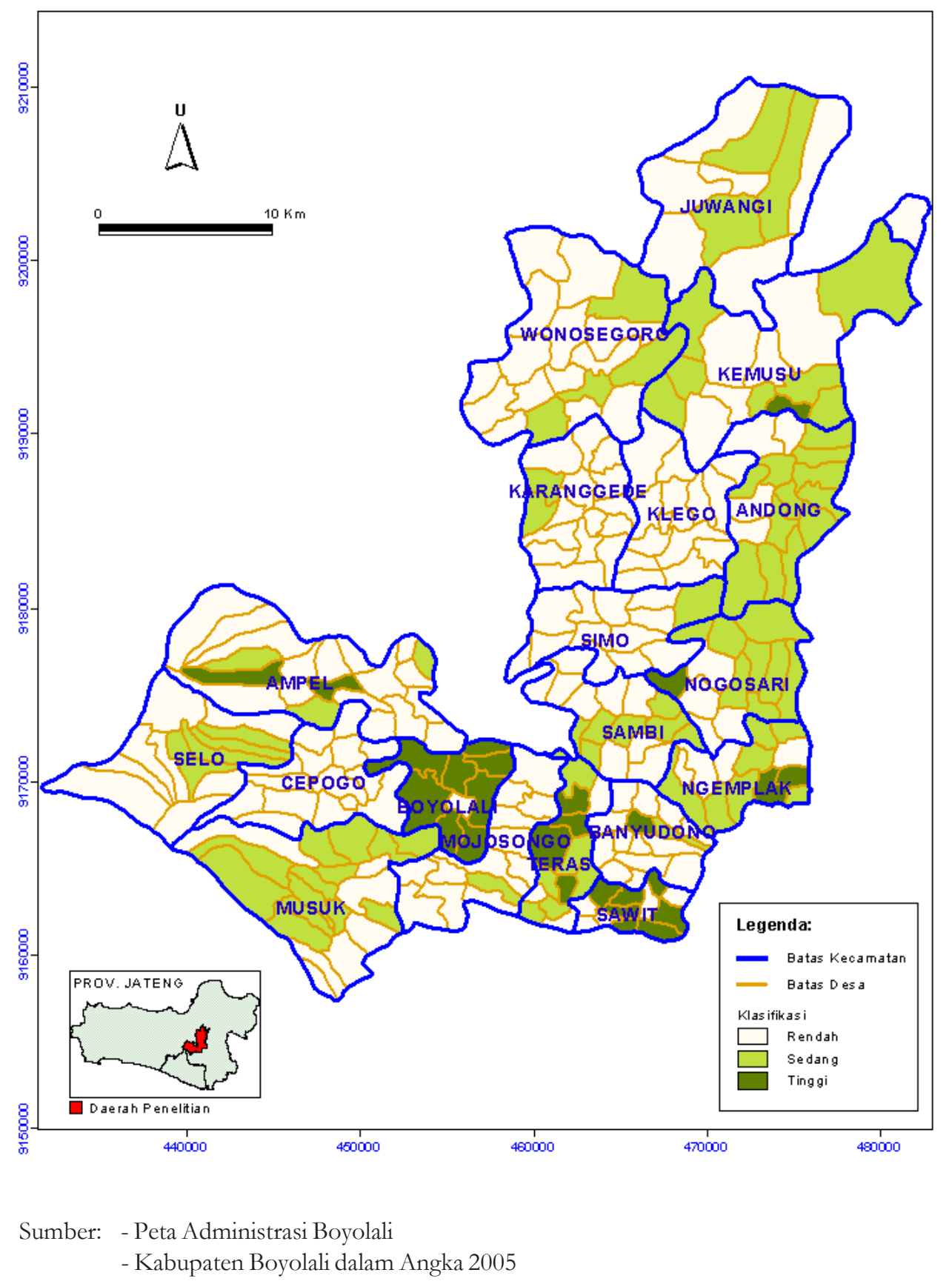

Gambar 3. Peta Sebaran Klasifikasi Tingkat Aksesibilitas Masing-masing Desa di Kabupaten Boyolali 
Tabel 5. Keselarasan Perkembangan Wilayah dan Kemiskinan

\begin{tabular}{lcc}
\hline \hline Keselarasan & Jumlah Desa & Persen \\
\hline Tidak selaras & 29 & 10,9 \\
Cukup selaras & 102 & 38,2 \\
Selaras & 136 & 50,9 \\
\hline Total & $\mathbf{2 6 7}$ & $\mathbf{1 0 0 , 0}$ \\
\hline
\end{tabular}

Sumber: Hasil Analisis Data Sekunder Kecamatan Dalam Angka 2005

Hasil penelitian menunjukkan bahwa terdapat hubungan keselarasan antara tingkat perkembangan wilayah dan kemiskinan (Gambar 5). Frekuensi hubungan keselarasan tersebut terlihat bahwa, terdapat 136 desa (50,9\%) mempunyai hubungan yang selaras. Asumsi logis bahwa desa-desa yang mempunyai tingkat perkembangan wilayah tinggi maka tingkat kemiskinannya rendah dan sebaliknya desa-desa dengan perkembangan wilayah rendah maka tingkat kemiskinannya tinggi. Di samping itu, desa yang perkembangan wilayahnya sedang mempunyai tingkat kemiskinan sedang.

Sebanyak 102 desa $(38,3 \%)$ mempunyai hubungan cukup selaras, yaitu desa-desa dengan perkembangan wilayah sedang mempunyai tingkat kemiskinan rendah atau tinggi, desa-desa yang mempunyai perkembangan wilayah rendah mempunyai tingkat kemiskinan sedang dan desa yang mempunyai perkembangan wilayah tinggi mempunyai tingkat kemiskianan sedang.

Hubungan yang tidak selaras antara perkembangan wilayah dengan kemiskinan terdapat pada 29 desa (10,9\%). Hubungan tidak selaras terjadi karena desa-desa dengan tingkat perkembangan wilayah rendah, tetapi mempunyai tingkat kemiskinan yang rendah serta desa-desa dengan perkembangan wilayah tinggi tetapi mempunyai tingkat kemiskinan yang tinggi pula.

\section{KESIMPULAN DAN SARAN}

\section{Kesimpulan}

1. Terdapat variasi distribusi tingkat kemiskinan, tingkat kemiskinan di Kabupaten Boyolali tergolong cukup tinggi mencapai $75,70 \%$ dan sebanyak $16,9 \%$ desa mempunyai tingkat kemiskinan tinggi, serta sebesar 7,5\% desa mempunyai tingkat kemiskinan rendah. Wilayah yang mempunyai resources endowment yang relatif rendah (wilayah pertanian lahan kering) ternyata tingkat kemiskinannya lebih tinggi dibanding wilayah yang mempunyai resources endowment lebih tinggi (wilayah pertanian sawah).

2. Terdapat hubungan negatif antara tingkat perkembangan wilayah dengan tingkat kemiskinan. Desa-desa yang mempunyai tingkat perkembang-an wilayah tinggi, tingkat kemiskinannya rendah, dan sebaliknya.

3. Faktor yang mempengaruhi perkembangan wilayah adalah ketersediaan fasilitas ekonomi, sosial dan 


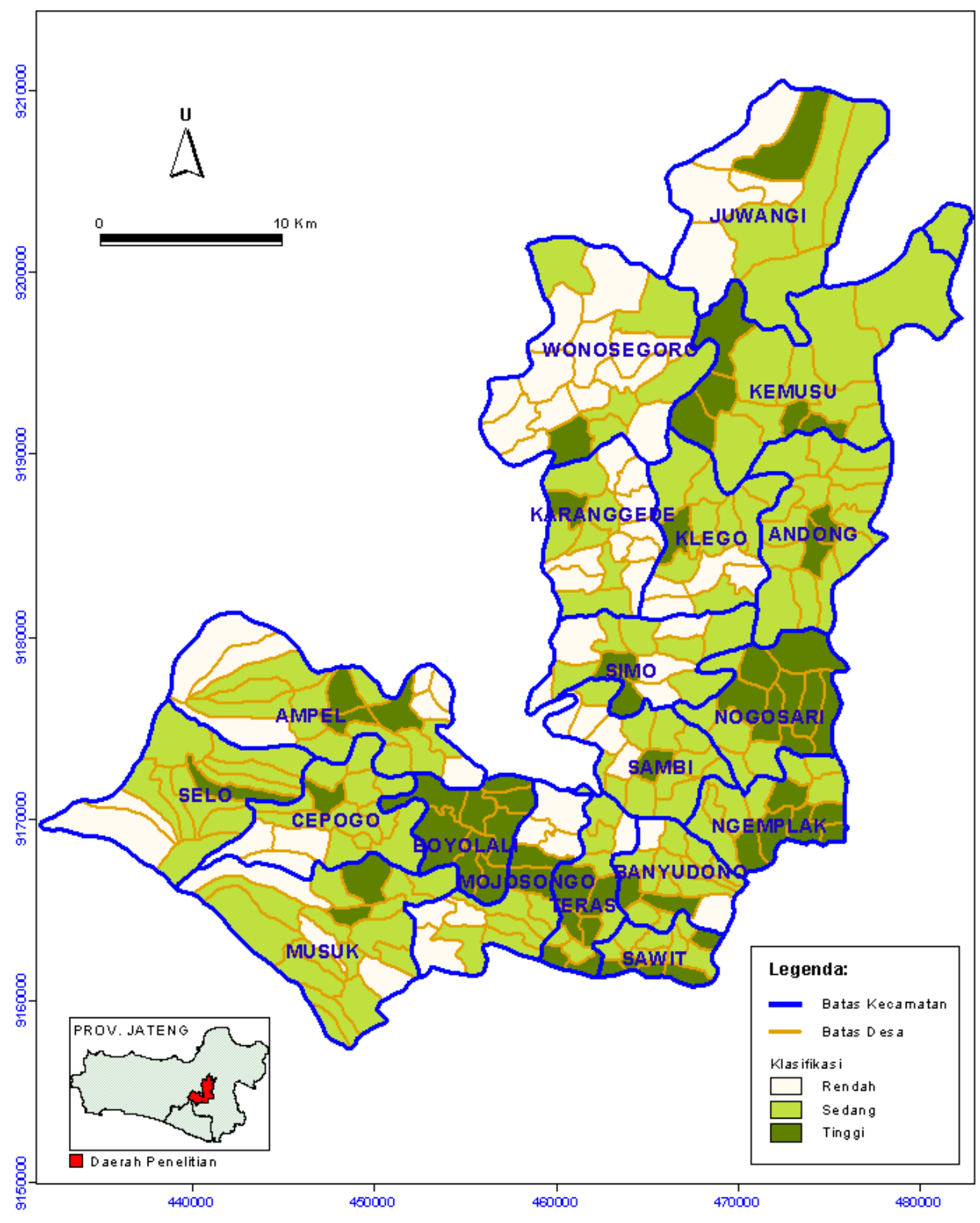

$\begin{aligned} \text { Sumber: } & \text { - Peta Administrasi Boyolali } \\ & \text { - Hasil Analisis }\end{aligned}$

Gambar 4. Peta Sebaran Klasifikasi Perkembangan Wilayah Masing-masing Desa di Kabupaten Boyolali 


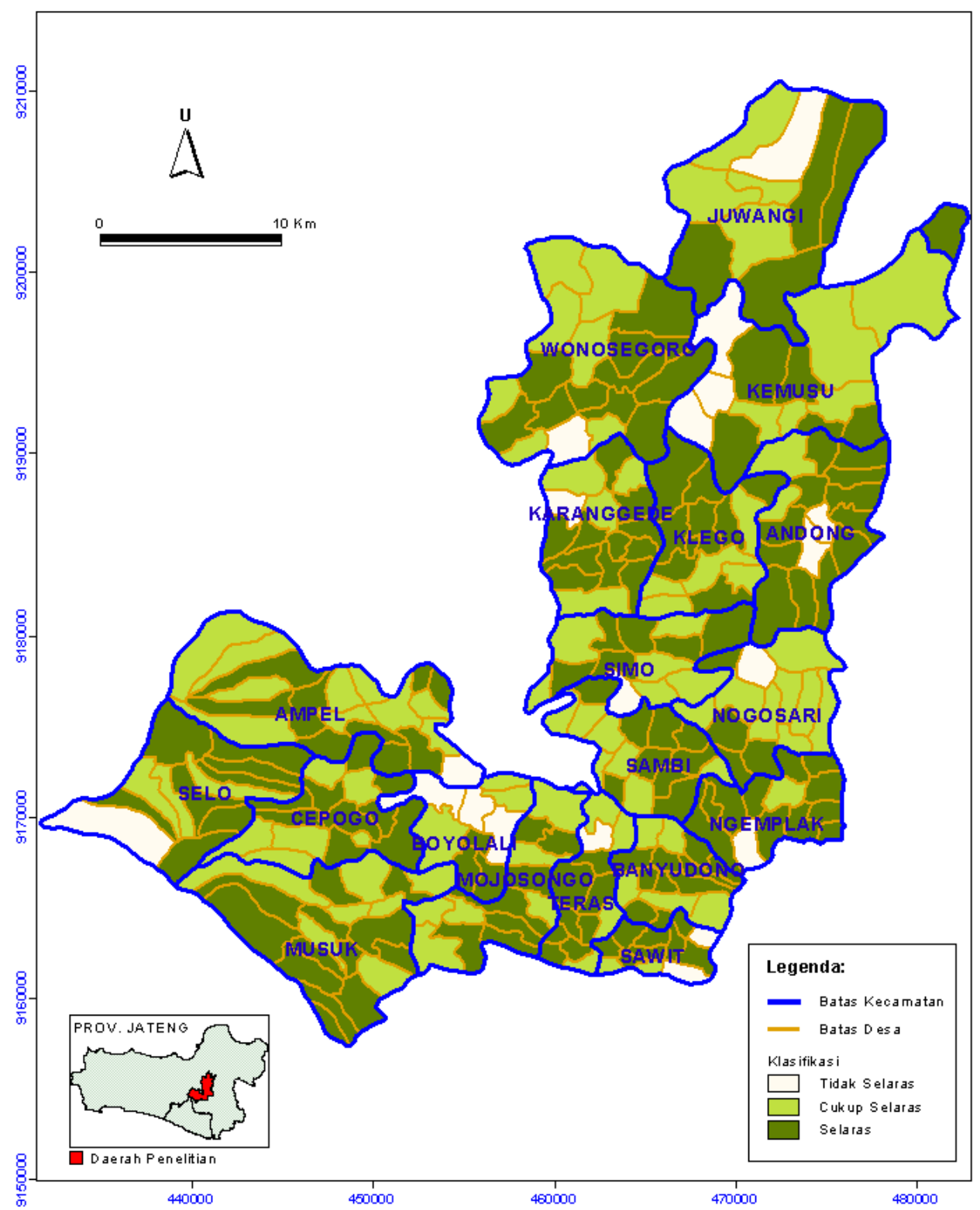

Sumber: - Peta Administrasi Boyolali Hasil Analisis

Gambar 5. Peta Keselarasan antara Perkembangan Wilayah dan Kemiskinan Masing-masing Desa di Kabupaten Boyolali 
aksesibilitas. Desa yang mempunyai perkembangan wilayah yang tinggi, mempunyai tingkat kemiskinan yang rendah, dan sebaliknya.

\section{Saran}

Program penanggulangan kemiskinan perlu dipadukan dengan program pengembangan wilayah, khususnya berkaitan dengan program pembagunan fasilitas pendidikan, kesehatan, perdagangan dan prasarana transportasi. Pembangunan fasilitas-fasilitas tersebut hendaknya diprioritaskan pada wilayah-wilayah relatif jauh dari kota. yang umumnya mempunyai tingkat kemiskinan tinggi.

\section{UCAPAN TERIMA KASIH}

Ucapan terima kasih penulis sampaikan kepada Direktorat Jenderal Pendidikan Tinggi, yang telah memberikan dana penelitian fundamental ini. Ucapkan terima kasih yang tulus juga penulis sampaikan pada saudara Tri Murtopo dan Mutaqin yang telah membantu dalam pengumpulan data serta analisa data, semoga amal kebajikannya mendapat balasan dari Allah, amin.

\section{DAFTAR PUSTAKA}

Badan Pusat Statistik Kabupaten Boyolali. Kabupaten Boyolali dalam Angka 2005.

BAPPEDA dan BPS Kabupaten Boyolali. 2004. Kecamatan dalam Angka (19 Kecamatan). Boyolali.

Boyolali.

2005. Kecamatan dalam Angka (19 Kecamatan).

Prahasta, Edy. 2002. Sistem Informasi Geografis Tutorial ArcView. Bandung.

Pemantauan dan Evaluasi Pelaksanaan Program Kompensasi Pengurangan Subsidi Bahan Bakar Minyak (PKPS BBM) tahun 2005 Oleh Perguruan Tinggi. Kementerian Koordinator Bidang Kesejahteraan Rakyat Bekerjasama dengan Universitas Muhammadiyah Surakarta.

Pemerintah Kabupaten Boyolali. 2004. Rencana Tata Ruang Wilayah(RTRW) Kabupaten Boyolali Tabun 2004-2014. Boyolali.

Musiyam, Muhammad, 1998. Pembangunan dan Kemiskinan: Tinjauan Kritis Pergeseran Strategi Penanggulangan Kemiskinan dari Pertumbuhan Sampai Pemberdayaan. Forum Geografi No: 23 (XII).

Tjokrowinoto, Moeljarto. 1996. Pembangunan: Dilema dan Tantangan. Yogyakarta: Pustaka Pelajar.

Astuti, Wahyuni Apri. 1998. Ciri-Ciri Kemiskinan di Perkotaan (Studi Komunitas Rumahtangga Miskin di Kalurahan Sangkrah Kotamadia Surakarta). 